\title{
The Presence of High and Low Incidence Districts of Australia Antigen in Miyagi Prefecture
}

\author{
Nakao Ishida, ${ }^{*}$ Takusei Umenai, ${ }^{*}$ Ryoichi Shirachi, \\ Takehiko Shiratori and Jiro Konno \\ Department of Bacteriology, ${ }^{*}$ Tohoku Uniuersity School of \\ Medicine and Miyagi Prefectural Institute of Public \\ Health, Sendai
}

Ismida, N., Umenai, T., Shirachi, R., Shiratori, T. and Konno, J. The Presence of High and Low Incidence Districts of Australia Antigen in Miyagi Prefecture. Tohoku J. exp. Med., 1972, 107 (2), 201-202— Age distribution of per cent positives of Australia (Au) antigen in several counties of Miyagi Prefecture was compared. Although the average incidence throughout the Prefecture was $1.7 \%$, the highest incidence of $4.5 \%$ was found in Kurikoma district and the lowest incidence of $0.3 \%$, in Marumori district. For the explanation of such a difference, no particular geographic and anthropological difference could be found. However, the age distribution of antibody was different between these two districts.

Au antigen; hepatitis; epidemiology

A previous report (Shirachi et al. 1972) described an incidence of $1.7 \%$ of Auantigen among blood donors of Miyagi Prefecture. Different incidences of Au antigen among the population of different counties or districts were also noticed. In this report, the age distributions of $\mathrm{Au}$ antigen and antibody in one of high incidence counties (Kurikoma) and one of low incidence counties (Marumori) were compared to the average distributions throughout the Prefecture.

In Kurikoma 787 serum specimens were collected and in Marumori, 362. The specimens which were tested are listed in the Tables 1 and 2 . No hepatitis outbreak was reported in the two areas for these 10 years. The presence of Au antigen was tested by immunoelectrosyneresis (IES) and of antibody was tested by the passive hemagglutination test (Imai et al., 1971). Other experimental details were fully described in the previous communication (Shirachi et al. 1972).

The results obtained on antigen distribution in the two districts are compared in Table 1. The distribution of Au antigen in Kurikoma and Marumori were $4.5 \%$ and $0.3 \%$, respectively. The higher incidence in Kurikoma compared to that in Marumori is evident in all age groups except persons 3-5 years old. There is a tendency that the older the age, the lower the detection rate in Kurikoma, although the difference between age groups is not statistically significant. In Marumori, only one of 362 samples was positive. This was from a person 35 years old. The discovery of such a low incidence district was never experienced in our 3 years of study. However, this low incidence of antigen distribution does not mean that there had been no experience of Au antigen in that district. This is clearly illustrated in the study of antibody distribution as shown in Table 2. Almost all the age groups in Marumori had a higher rate than in Kurikoma.

Graphic illustration of age distributions of both antigen and antibody positive rate in the high and low districts and the entire Prefecture is shown in Fig. 1. Both the antigen and antibody distribution curves were similar for Kurikoma and the average. However, the patterns for Marumori were markedly different from Kurikoma and the average.

Received for publication, April 6, 1972. 
TABLE 1. Age distribution of Australia antigen in 2 district populations

\begin{tabular}{c|r|r|r|r|r|r}
\hline & \multicolumn{3}{|c|}{ Kurikoma } & \multicolumn{3}{c}{ Marumori } \\
\cline { 2 - 7 } Age & $\begin{array}{c}\text { No. } \\
\text { tested }\end{array}$ & $\begin{array}{c}\text { No. } \\
\text { posi- } \\
\text { tive }\end{array}$ & $\%$ & $\begin{array}{c}\text { No. } \\
\text { tested }\end{array}$ & $\begin{array}{c}\text { No. } \\
\text { posi- } \\
\text { tive }\end{array}$ & $\%$ \\
\hline $3-5$ & 19 & 0 & 0 & 14 & 0 & 0 \\
$6-8$ & 56 & 4 & 7.1 & 75 & 0 & 0 \\
$9-11$ & 65 & 3 & 4.6 & 90 & 0 & 0 \\
$12-14$ & 87 & 3 & 3.5 & 53 & 0 & 0 \\
$15-20$ & 99 & 5 & 5.1 & 9 & 0 & 0 \\
$21-30$ & 142 & 7 & 4.9 & 23 & 0 & 0 \\
$31-40$ & 140 & 5 & 3.6 & 27 & 1 & 3.7 \\
$41-50$ & 153 & 7 & 4.6 & 25 & 0 & 0 \\
$51-$ & 26 & 1 & 3.8 & 46 & 0 & 0 \\
\hline Total & 787 & 35 & 4.4 & 362 & 1 & 0.3 \\
& & & &
\end{tabular}

TABLE 2. Age distribution of Australia antibody in 2 district populations

\begin{tabular}{c|c|c|c|r|r|r}
\hline \multirow{2}{*}{ Age } & \multicolumn{3}{|c|}{ Kurikoma } & \multicolumn{3}{c}{ Marumori } \\
\cline { 2 - 6 } & $\begin{array}{c}\text { No. } \\
\text { tested }\end{array}$ & $\begin{array}{c}\text { No. } \\
\text { posi- } \\
\text { tive }\end{array}$ & $\%$ & $\begin{array}{r}\text { No. } \\
\text { tested }\end{array}$ & $\begin{array}{c}\text { No. } \\
\text { posi- } \\
\text { tive }\end{array}$ & $\%$ \\
\hline $3-5$ & 19 & 0 & 0 & 14 & 0 & 0 \\
$6-8$ & 56 & 2 & 3.6 & 75 & 14 & 18.7 \\
$9-11$ & 65 & 7 & 10.8 & 90 & 20 & 22.2 \\
$12-14$ & 87 & 9 & 10.3 & 53 & 11 & 20.8 \\
$15-20$ & 33 & 5 & 15.2 & 9 & 2 & 22.2 \\
$21-30$ & 22 & 4 & 18.2 & 23 & 7 & 30.4 \\
$31-40$ & 29 & 4 & 13.8 & 27 & 10 & 37.0 \\
$41-50$ & 46 & 9 & 19.6 & 25 & 6 & 24.0 \\
$51-$ & 26 & 6 & 23.1 & 46 & 3 & 6.5 \\
\hline Total & 383 & 46 & 12.0 & 362 & 73 & 20.2
\end{tabular}
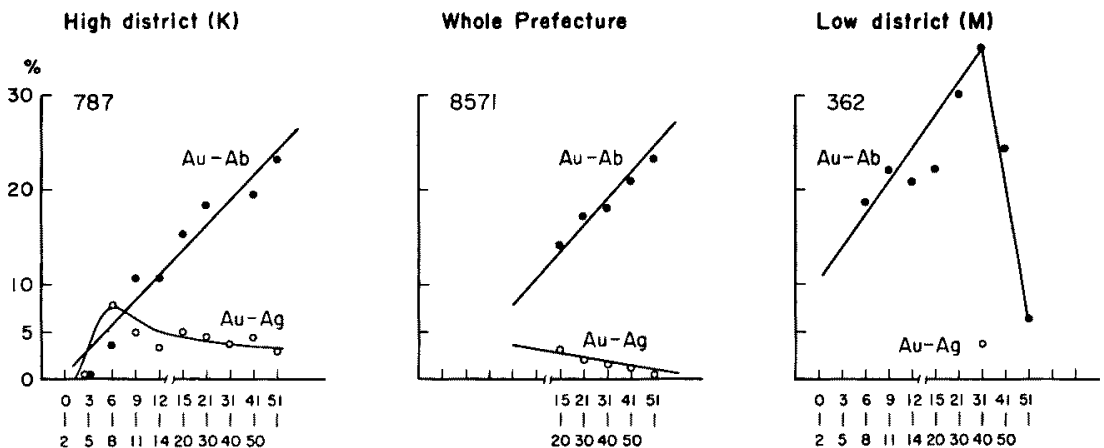

Fig. 1. Different distributions of Au antigen and antibody between 2 districts compared to those of whole prefectural population.

One explanation of such a different antigen distribution between different districts may be due to the difference in horizontal spread of the etiological agent at younger age. An alternative possibility may be the difference in host susceptibility, such as the segregation of the gene responsible for persistence of Au antigen as an autosomal trait (Sutnick et al. 1971). This has been confirmed with limited studies and supported by the hypotheses of inherited susceptibility. However, we could not find any supporting evidence for the latter when the same sanitary, geographic and anthropological situations of the two districts are taken into consideration.

\section{References}

1) Imai, M., 'Takahashi, T., Mayumi, T. \& Okochi, K. (1971) Detection of Australia antibody by passive hemagglutination test. Igaku no Ayumi (Jap.), 78, 759-760.

2) Shirachi, R., Sukeno, N., Sasaki, T., Umenai, T., Shiratori, T., Konno, J. \& Ishida, N. (1972) Frequency of Australia antigen in volunteer blood donors in Miyagi Prefecture. Tohoku J. exp. Med., 106, 211-212.

3) Sutnick, A.I., London, W.T. \& Blumberg, B.S. (1971) Australia antigen: a genetic basis for chronic liver diseases and hepatoma? Ann. intern. Med., 74, 442-444. 